\title{
Indian Basic Structure Jurisprudence in the Islamic Republic of Pakistan: Reconfiguring the Constitutional Politics of Religion
}

\author{
Matthew J NELSON* \\ School of Oriental and African Studies, University of London, United Kingdom \\ mn6@soas.ac.uk
}

\begin{abstract}
In both India and Pakistan, parliament is constitutionally endowed with 'constituent power', that is, the power to introduce constitutional amendments via procedures laid down in the constitution itself. Duly promulgated amendments, however, are occasionally struck down when Supreme Court judges see them as violating what the judges themselves define as the 'essential features' of each country's constitutional 'basic structure'. I trace the migration of basic structure jurisprudence from India to Pakistan, focusing on the ways in which it has elevated the power of judges over that of elected officials in the realm of religion-state relations. Specifically, I highlight the ways in which judicial independence vis-à-vis judicial appointments has been described as an essential feature of each country's constitution, greatly enhancing the autonomous power of judges to mould constitutional benches that, in turn, define India's constitutional understanding of secularism and Pakistan's relationship with Islam.
\end{abstract}

Constitutional articles providing elected legislators with constituent power, that is, the power to amend the constitution itself, may be limited by explicit clauses defining certain constitutional elements as unamendable (consider, for instance, Article 79(3) of the Basic Law for the Federal Republic of Germany prohibiting any amendment restricting 'human dignity' or the principles, structures, and institutions establishing Germany as a 'democratic and social federal state') as well as by an increasingly widespread notion that each constitution comes with an implied, but still unamendable, 'basic structure'. ${ }^{1}$ Scholars like Yaniv Roznai have documented the extent to which judges around the world have been drawn to a doctrine of judicial review suggesting that a constitution's 'essential features' may be unamendable even when those features are not spelled out as such within the constitutional text - a doctrine best illustrated in the postcolonial jurisprudence of India. ${ }^{2}$ This jurisprudence, I argue, has travelled to Pakistan in ways that could reconfigure the relative importance of judicial and parliamentary power in Pakistan's constitutional relationship with Islam.

Departing from British notions of unfettered parliamentary sovereignty, India's Constituent Assembly (1946-49) embraced a list of enumerated and enforceable rights as well as a constitutional separation of powers closely tied to the establishment of an

* Reader, Department of Politics, School of Oriental and African Studies. The author wishes to thank the Centre for Asian Legal Studies at the Faculty of Law, National University of Singapore, for funding this project.

1 For explicit substantive unamendability, see Yaniv Roznai, Unconstitutional Constitutional Amendments: The Limits of Amendment Powers (OUP 2017) 15-38, 235-74.

2 ibid; Yaniv Roznai, 'Unconstitutional Constitutional Amendments - The Migration and Success of a Constitutional Idea’ (2013) 61(3) American Journal of Comparative Law 657. See also Richard Albert, 'Nonconstitutional Amendments' (2009) 22(1) Canadian Journal of Law and Jurisprudence 5; Aharon Barak, 'Unconstitutional Constitutional Amendments' (2011) 44(3) Israel Law Review 321. 
independent judiciary. India's Supreme Court, however, quickly came to appreciate that parliament's authority to amend India's Constitution could pose a risk, both to fundamental rights and to the Court's independence. To address this risk, beginning in the late-1960s and early-1970s, India's Supreme Court gave itself the power to elucidate certain 'essential features' of India's Constitution - for example, fundamental rights and an independent judiciary - and insisted that the Court was empowered to annul constitutional amendments duly promulgated by parliament if they were deemed (by the Court) to abrogate or fundamentally alter India's constitutional 'basic structure'. ${ }^{3}$

India's Supreme Court identified a list of essential features including, but not limited to, judicial independence, a parliamentary form of government, a 'secular' approach to religion-state relations (grounded in fundamental rights), and federalism. In what follows, I focus on the first three of these features, drawing attention to the ways in which India's Supreme Court came to see the independence of the judiciary as the first among equals. Specifically, I argue that this focus on judicial independence elevated the power of the Court to manage the link between India's 'parliamentary form of government' and its 'secular' approach to religion.

My focus, however, is not limited to India. I am particularly interested in the ways in which India's understanding of 'implied' restrictions on parliament's constituent power migrated from India to Pakistan. ${ }^{4}$ In this context, I stress the ways in which the Pakistan Supreme Court's references to the essential (or 'salient') features of Pakistan's Constitution are similar to those in India, with one key difference: in Pakistan, the constitution's salient features do not stress a parliamentary form of government accompanied by secularism. Instead, they include a parliamentary form of government 'blended with Islamic provisions' alongside - as in India - judicial independence, fundamental rights, and federalism. ${ }^{5}$ However, the ways in which the Pakistan Supreme Court came to position itself - within this list - as the first among equals mirror similar patterns in India. This elevates the power of the Court to manage the link between Pakistan's parliamentary form of government and religion-state relations (ie, the link between parliament and Islam).

Within both India and Pakistan, supreme court majorities have slowly come to agree that constitutional amendments satisfying all the procedural requirements for making such amendments, but which nevertheless threaten the constitution's essential features (or basic structure), can be struck down in the course of judicial review. This appreciation for the possibility of substantively 'unconstitutional constitutional amendments' is remarkable in light of existing constitutional clauses explicitly favouring parliament's constituent power. In India, Article 368 states that 'parliament may, in exercise of its constituent power, amend ... any provision of this Constitution' and, in Pakistan, Articles 239(5) and 239(6) state that 'no amendment ... shall be called

3 See eg Kesavananda Bharati Sripadagalvaru v State of Kerala, AIR 1973 SC 1461 (Supreme Court of India).

4 See Roznai, Unconstitutional Constitutional Amendments (n 1) 49-52; Paula R Newberg, Judging the State: Courts and Constitutional Politics in Pakistan (CUP 1995) 237-41, 243-44; Martin Lau, The Role of Islam in the Legal System of Pakistan (Brill 2006) 81-88. For related work on the migration (and transformation) of constitutional ideas, see Michel Rosenfeld and András Sajó, 'Spreading Liberal Constitutionalism: An Inquiry into the Fate of Free Speech Rights in New Democracies' in Sujit Choudhry (ed), The Migration of Constitutional Ideas (CUP 2006) 142; Matthew Nelson, 'Constitutional Migration and the Meaning of Religious Freedom: From Ireland and India to the Islamic Republic of Pakistan’ Journal of Asian Studies (forthcoming 2019).

5 See also Vivek Krishnamurthy, 'Colonial Cousins: Explaining India and Canada's Unwritten Constitutional Principles’ (2009) 34(1) Yale Journal of International Law 207. 
into question by any court' and, 'for the removal of doubt, ... there is no limitation whatever on the power of ... parliament to amend ... the constitution' ${ }^{6}$

My question is: what do ongoing supreme court efforts to move beyond a plain reading of Articles 368 (India) and 239 (Pakistan) mean for constitutional matters implicating religion? How has basic structure jurisprudence affected not only India's relationship with secularism, but also, in Pakistan, the jurisprudence shaping the link between parliament and Islam?

In both countries, I highlight the ways in which connections between basic structure jurisprudence and religion are indirect. Specifically, I show how these connections have been mediated by supreme court assertions regarding judicial independence in the realm of judicial appointments. Broadly, my argument concerns the role of basic structure decisions regarding judicial autonomy in assembling courts empowered to draw on their own understanding of each constitution's 'secular' or 'Islamic' essential features. ${ }^{7}$ In India, basic structure decisions annulling constitutional amendments seeking to enhance parliament's role in judicial appointments have been closely tied to basic structure decisions enhancing the power of an 'independent' judiciary over elected legislators, even to the point of removing state-level legislators for their failure to reflect forms of secularism defined by the Court itself. In Pakistan, basic structure decisions pertaining to judicial independence, autonomy, and appointments have enhanced the power of the judiciary in two ways (both pertaining to religion). The first concerns the extent to which the military might be able to pursue 'Islamic' terrorists via constitutional amendments establishing parallel military courts. The second, turning to the core of this article, concerns judicial efforts to assess the 'Islamic' credentials of individual parliamentarians (ie, court-based efforts to determine the 'Islamic' status of parliament itself).

In both states, this basic structure focus on judicial independence and appointments has shaped the assembling - indeed the moulding - of supreme courts empowered to apply their discretion in cases regarding the disqualification of elected officials considered insufficiently 'secular' (India) or 'Islamic' (Pakistan). In India, this has involved the imposition of President's Rule for those seen by the courts as insufficiently 'secular'; in Pakistan, this has involved the disqualification of parliamentarians seen as insufficiently honest in an 'Islamic' sense. As such, the link between basic structure jurisprudence and religion-state relations can be understood with reference to a much wider competition between parliamentary and judicial power. This competition involves judicial appointments and parliamentary disqualifications, with key actors occupying shifting positions: religious legislators versus judges, each claiming to defend constitutional 'secularism' in India; parliamentarians versus judges, each claiming to defend 'Islamic' constitutionalism in Pakistan.

Within Pakistan, I do not claim that references to Islam have, in some sense, produced an 'Islamic' approach to (Indian) basic structure jurisprudence. Instead, I argue that, in adapting forms of basic structure jurisprudence, Pakistan's Supreme Court has (as in India) privileged judicial autonomy over parliamentary power both in

6 In the first Constitution of the Islamic Republic of Pakistan 1956 (1956 Constitution), art 216 provided that constitutional amendments duly promulgated by parliament 'shall not be questioned in any court'. This clause was removed in the second Constitution of the (re-named) Republic of Pakistan 1962 (1962 Constitution) as well as the third Constitution of the (again re-named) Islamic Republic of Pakistan 1973 (1973 Constitution). Arts 239(5) and 239(6) were added to the 1973 Constitution in 1985.

7 See District Bar Association, Rawalpindi v Federation of Pakistan, PLD 2015 SC 401 (Supreme Court of Pakistan); Supreme Court Advocates-on-Record Association v Union of India (2016) 5 SCC 1. 
matters pertaining to judicial appointments and in parliament's constitutional relationship with religion. In what follows, this article unfolds in three parts. Part I introduces the constitutional position occupied by religion in Pakistan while, at the same time, highlighting some of the ways in which Pakistan's Constitution borrowed from India's. Parts II and III turn to patterns of judicial self-aggrandizement vis-à-vis religion in each country's basic structure jurisprudence - first, with reference to 'secularism' in India (Part II) and, then, in more detail, with reference to 'Islam' in Pakistan (Part III).

\section{I. ‘RELIGION’ IN THE CONSTITUTION OF PAKISTAN}

Within Pakistan's first Constituent Assembly, the most important constitutional provision concerning religion was approved in 1949 and sustained in each constitution thereafter. Known as the Objectives Resolution, this initially preambular provision struck a delicate balance between the authority of 'Islamic' principles and the authority of the Pakistani 'people'. It provides that, while 'sovereignty over the entire universe belongs to Almighty Allah' and the authority of the people would be exercised 'within the limits prescribed by Him' as 'a sacred trust', state authority would always be exercised by 'the people' of Pakistan via their 'chosen representatives' working alongside an independent judiciary.

Apart from this carefully balanced Objectives Resolution, references to religion appeared in several other parts of the constitution, including Chapter 1 focusing on Fundamental Rights. ${ }^{8}$ It is worth noting, at this point, that Pakistan has had three constitutions since its independence in 1947: one in 1956, one in 1962, and one in 1973. The fundamental rights provisions mentioned in this article were retained, but often renumbered, over time. In what follows, I use the numbering in the Constitution of the Islamic Republic of Pakistan 1973 (1973 Constitution).

Interestingly, within Chapter 1 on Fundamental Rights, Articles 20(a) and 20(b) mirror Articles 25 and 26 in India, specifying that - subject to law, morality, and public order - each individual would enjoy a right to profess, practice, and propagate his or her religion, even as each denomination (or sect) had the right to establish, maintain, and manage its own religious institutions. ${ }^{9}$ In fact, recalling Articles 27 and 28 in India, Articles 21 and 22 in Pakistan specify that no citizen would be compelled to pay any special tax or attend any form of religious instruction or ceremony related to any denomination other than his own. Articles 26-27 in Pakistan further mirror Articles 1516 in India by extending this principle of religious non-discrimination to public spaces and employment. Within Pakistan's list of fundamental rights, however, Article 19 on freedom of speech states, after 1973, that 'free speech' did not extend to any utterance that might impinge on 'the glory of Islam'. In fact, this space for Islam was further secured via the specification of Islam as Pakistan's state religion (Article 2) and various other provisions.

Reiterating Pakistan's Objectives Resolution, for instance, Article 31 (within Pakistan's list of non-justiciable 'Principles of Policy') states that 'steps shall be taken to enable ... Muslims ... to order their lives in accordance with the fundamental

8 With reference to Fundamental Rights, art 8 provides that, apart from the laws specified in the Constitution's First Schedule, any law deemed to abrogate or conflict with fundamental rights shall, to the extent of that conflict, be 'void'; see also Constitution of India 1950, art 13.

9 See Nelson ‘Constitutional Migration and the Meaning of Religious Freedom’ (n 4). 
principles ... of Islam' ${ }^{10}$ In fact, to facilitate this, Article 227 provides that laws considered 'repugnant' to the injunctions of Islam would not be enacted in Pakistan, with Articles 228-30 establishing an advisory Council of Islamic Ideology appointed by the President to guide both the national and provincial assemblies in this task. With the exception of the 'Islamic' restriction in Article 19, all of these provisions were included in the first Constitution of the Islamic Republic of Pakistan 1956 (1956 Constitution) and then reproduced in the 1973 Constitution. ${ }^{11}$

Pakistan's President and elected representatives, however, were also constrained by a series of oaths spelled out in the Constitution's Third Schedule. Substantially revised in 1973, these oaths aimed to ensure that Pakistan's President and Prime Minister would be 'Muslims' while, at the same time, ensuring that neither official belonged to a heterodox religious minority known as the Ahmadiyya. ${ }^{12}$ Article 62 (as amended by a parliament convened under Pakistan's second military dictator, General Zia-ul-Haq, in 1985) also states that every Muslim parliamentarian must have 'adequate knowledge of Islamic teachings', 'practice [the] obligatory duties prescribed by Islam', and 'abstain from major sins' (Article 62(1)(e)) whilst remaining 'righteous, honest, and ameen' (that is, honest in a religious sense: Article 62(1)(f)). Again, the link between parliamentary power and Islam was unmistakable: each occupied one end of a rather delicate religious-cum-political balance.

After 1980, however, the dictatorship of General Zia-ul-Haq (1977-88) took this balance a step further with specific reference to the judiciary. In 1980, Zia introduced a suite of amendments pushing beyond the advisory powers of Pakistan's Council of Islamic Ideology (Articles 228-30) to establish a Federal Shariat Court and a Shariat Appellate Bench of Pakistan's existing Supreme Court (Article 203). Each of these courts, Zia noted, would be empowered to decide whether any legal provision - apart from the Constitution itself, a set of laws known as 'Muslim personal laws', and various fiscal and financial laws - might be considered 'repugnant' to the injunctions of Islam. These courts were empowered to render such laws ineffective until an alternative could be framed by Pakistan's elected representatives on the order of the President or, in the case of provincial laws, the President's appointed Governors.

Together, these provisions stressed that, although ultimate sovereignty belonged to 'Almighty Allah', the power of the state was firmly tied to: (1) the power of elected representatives charged with formulating legislation; and (2) a two-part judiciary charged with reviewing that legislation.

However, the tension between legislators and judges was not confined to ordinary legislation. Above all, it was tied to competing ideas regarding parliament's constituent power. In India, this competition took the form of periodic judicial encroachments on the notion that parliament may, in exercising its power, 'amend ... any provision of

10 The inclusion of non-justiciable 'Principles of Policy' was modelled on India's 'Directive Principles of State Policy' (modelled on Ireland's 'Directive Principles of Social Policy').

11 In Pakistan's 1962 Constitution, promulgated by General Ayub Khan in 1962, all of these rights were reduced to non-justiciable 'Principles of Law-Making'. Following massive protests, however, they were restored as enforceable 'fundamental rights' in the first amendment to that Constitution in 1963.

12 The Ahmadiyya follow a late-nineteenth century religious reformer known as Mirza Ghulam Ahmad (d 1908) who claimed to receive revelations (like a prophet) after the Prophet Mohammad. (Muslims typically regard Mohammad as the final prophet of God.) Since 1973, the Ahmadiyya have been described, within a revised provision of art 260 regarding constitutional definitions, as 'nonMuslims'. Pakistan's President and Prime Minister are required to swear an oath that (a) they believe in Mohammad as 'the last of the Prophets', and, with every provincial governor, senator, or member of a national or provincial assembly, that (b) they will strive to maintain 'the Islamic Ideology which is the basis for the creation of Pakistan': 1973 Constitution, third sch. 
[India's] Constitution' including fundamental rights (and, therein, India's approach to secularism). In Pakistan, it took the form of related encroachments on the notion that 'there is no limitation whatever on the power of ... parliament to amend any ... provisions of the constitution', including those concerning Islam. ${ }^{13}$

Indeed, with reference to Pakistan's constitutional politics of religion, a crucial question emerges: is it possible for Pakistan's Supreme Court to draw on its notion of constitutional 'basic structure' to strike down a constitutional amendment as inconsistent with whatever the Court itself might choose to define as Pakistan's 'Islamic' features (notwithstanding the fact that Islamic injunctions are nowhere clearly defined in the constitution)? The answer, I argue, is 'yes'. In fact, existing trends already suggest that Pakistan's Supreme Court is poised to strike down any amendment that might seek to limit the discretionary power of the Court to define - and, then, disqualify - an incumbent Prime Minister as insufficiently 'Islamic' (see Part III, below).

Basic structure jurisprudence seems increasingly likely to figure prominently in South Asia's constitutional politics of religion. What follows is an account of how this link emerged - first in 'secular' India and, then, with more detail, in the 'Islamic' Republic of Pakistan.

\section{BASIC STRUCTURE IN INDIA: SECULARISM AND THE SEPARATION OF POWERS}

When the Constitution of India (1950 Constitution) was unveiled in 1950, Article 368 laid down the procedure for constitutional amendments. ${ }^{14}$ Within just fifteen months, these procedures had produced India's first constitutional amendment (1st Amendment) adding a new clause to Part III concerning Fundamental Rights. ${ }^{15}$ Framed as Article 31(b), this new clause created the Constitution's Ninth Schedule protecting various land reforms from allegations that they ignored a fundamental right to property, stating that 'none of the acts and regulations specified in the Ninth Schedule shall be deemed to be void ... on the ground that [they are] ... inconsistent with [fundamental rights]'. In short, recalling British notions of parliamentary sovereignty, India's 1st Amendment protected any parliamentary act that might be said to violate fundamental rights. ${ }^{16}$

A Supreme Court case known as Shankari Prasad v Union of India, however, challenged this amendment as a violation of Article 13(2) within Part III. Article 13(2) notes that 'the state shall not make any law which takes away or abridges [the] rights conferred by ... Part [III]'. Initially, the Court upheld the 1st Amendment, noting that parliament's constituent power extended even as far as fundamental rights. ${ }^{17}$ Yet, in a subsequent case known as Golak Nath v State of Punjab, the Court revised this position and offered a prospective judgment stating that henceforth, the restrictions outlined in

13 Crucially, India's Constitution abjured any explicit reference to 'secularism' until 1976, when, via India's forty-second constitutional amendment, a preambular reference to India as a 'sovereign socialist secular democratic' republic was added during the authoritarian interregnum of Prime Minister Indira Gandhi - India’s so-called Emergency (1975-77).

14 These procedures specified a need for support from two-thirds of both legislative houses and the president's assent (as well as ratification by a majority of states for amendments concerning them).

15 The Constitution (First Amendment) Act 1951 (1st Amendment).

16 See Lloyd I Rudolph and Susanne Hoeber Rudolph, In Pursuit of Lakshmi: The Political Economy of the Indian State (University of Chicago Press 1987) 109-110.

17 Shankari Prasad v Union of India, AIR 1951 SC 450 (Supreme Court of India). 
Article 13(2) would apply to 'any law' including constitutional amendments. ${ }^{18}$ In fact, in revising Shankari Prasad, the Court in Golak Nath declared that parliament had no power to amend India's fundamental rights - including, by extension, rights concerning religion.

Decided by a narrow majority of 6 to 5, Golak Nath prompted India's parliament to introduce India's twenty-fourth constitutional amendment (24th Amendment). ${ }^{19}$ Within Part III, this amendment inserted a new provision (Article 13(4)) allowing constitutional amendments affecting - even removing - all of the fundamental rights mentioned in Part III. At the same time, it introduced Article 368(1) to declare that 'parliament may, in exercise of its constituent power, amend ... any provision of this Constitution in accordance with the procedure laid down in this article'. ${ }^{20}$ In short, India's 24th Amendment sought to block the application of Golak Nath, setting in train a series of Supreme Court battles regarding the scope of parliament's power particularly parliament's constituent power vis-à-vis the delineation of fundamental rights.

Specifically, the 24th Amendment prompted a landmark basic structure case Kesavananda Bharati $v$ State of Kerala - wherein the Supreme Court struck down key parts of the 24th Amendment. ${ }^{21}$ In particular, the Court decided by a 7 to 6 majority that even if Article 368 allowed parliament to 'amend' any article of the Constitution, parliament was not empowered to 'abrogate' the Constitution's essential features (including, explicitly, 'secularism'). In short, the Court held that any article could be amended, but only up to a point: no amendment could extend as far as removing something deemed (by the Court) to reflect the Constitution's 'basic structure'. ${ }^{22}$

18 IC Golak Nath v State of Punjab, AIR 1967 SC 1643 (Supreme Court of India). Interestingly, Golak Nath draws on contemporaneous jurisprudence in Pakistan; see eg references to the 'basic structure of government' and the 'essential features of the constitution' in Fazlul Quader Chowdhry $v$ Muhammad Abdul Haque, PLD 1963 SC 486 (Supreme Court of Pakistan). Few stress this link; most stress the influence of Heidelberg University Professor of Law Dieter Conrad, his 1965 lectures at Benares Hindu University, and his collaboration with Golak Nath counsel MK Nambyar; see Roznai, Unconstitutional Constitutional Amendments (n 1) 44.

19 The Constitution (Twenty-fourth Amendment) Act 1971 (24th Amendment).

201950 Constitution, art 368(1) (emphasis added).

21 Kesavananda Bharati (n 3); see also Upendra Baxi, 'Some Reflections on the Nature of Constituent Power' in Rajeev Dhavan and Alice Jacob (eds), The Indian Constitution: Trends and Issues (NM Tripathi 1978) 122; David Gwynn Morgan, ‘The Indian “Essential Features” Case’ (1981) 30(2) International and Comparative Law Quarterly 307; Raju Ramachandran, 'The Supreme Court and the Basic Structure Doctrine’ in BN Kirpal et al (eds), Supreme But Not Infallible: Essays in Honour of the Supreme Court of India (OUP 2000) 107; A Lakshminath, Basic Structure and Constitutional Amendments: Limitations and Justiciability (Deep and Deep 2002); SP Sathe, Judicial Activism in India: Transgressing Borders and Enforcing Limits (OUP 2002) 63-89, 173-79, 193-94; Gary Jeffrey Jacobsohn, 'An Unconstitutional Constitution? A Comparative Perspective' (2006) 4(3) International Journal of Constitutional Law 460; Sudhir Krishnaswamy, Democracy and Constitutionalism in India: A Study of the Basic Structure Doctrine (OUP 2010).

22 In Golak Nath (n 18), the Supreme Court sought to restrict parliament's powers of constitutional amendment vis-à-vis fundamental rights; in Kesavananda (n 3), the Court placed fundamental rights within a wider class of 'essential features' while, at the same time, preserving the possibility of modification so long as those modifications did not abrogate the Constitution's overarching 'basic structure'. See also the Constitution of Norway 1814, art 122 (stating that amendments 'must never ... contradict the principles embodied in [the] constitution, but solely relate to modifications of particular provisions which do not alter the spirit of the constitution'). For similar arguments in 19th and early 20th century America and, then, early 21st century Pakistan, see Roznai, Unconstitutional Constitutional Amendments (n 1) 40-42, 223. 


\section{A. Basic Structure and the Separation of Powers}

Following the landmark decision in Kesavananda, India's Supreme Court simply extended its understanding of India's constitutional basic structure to address the parameters of judicial independence and, ultimately, constitutional 'secularism'.

In 1975, the Allahabad High Court ruled against Prime Minister Indira Gandhi in a petition alleging corruption in the course of her re-election. The High Court set aside Mrs Gandhi's re-election and barred her from standing for elections for another six years. However, when this decision was appealed to the Supreme Court, prompting widespread protests, Gandhi advised the President to declare a state of emergency. During this emergency, India's parliament introduced yet another constitutional amendment - the Thirty-ninth Amendment (39th Amendment) - specifically protecting electoral practices pertaining to the Prime Minister (and the Speaker of the lower house) from any judicial review. ${ }^{23}$ This amendment was challenged in a case known as Indira Nehru Gandhi v Raj Narain, commonly known as the 'Election' case. In this case, the Supreme Court held that the 39th Amendment undercut an essential feature of the 1950 Constitution, namely the balance of powers and, specifically, the independence of the judiciary. ${ }^{24}$

Almost immediately, however, this decision led the parliament to amend the Constitution yet again - this time, via the Forty-second Amendment (42nd Amendment). ${ }^{25}$ Foreshadowing subsequent debates regarding religion-state relations in both India and Pakistan, this 42nd Amendment added the word 'secular' to India's constitutional preamble as well as two new clauses concerning constitutional amendments:
(a) 'No amendment of this Constitution ... shall be called in[to] question in any court on any ground' (368(4)); and
(b) 'For the removal of doubts, it is hereby declared that there is no limitation whatever on the constituent power of Parliament to amend ... the provisions of this Constitution' (368(5)). ${ }^{26}$

Like the 39th Amendment, however, this amendment was struck down in the Supreme Court case of Minerva Mills Ltd v Union of India as a violation of judicial independence and, thereby, the separation of powers. ${ }^{27}$ In short, Indira Gandhi's efforts to prevent any judicial review of duly promulgated constitutional amendments led the Court to push its pre-Kesavananda focus on 'fundamental rights' toward a post-Kesavananda focus on the 'independent' power of the judiciary. ${ }^{28}$ These two elements were simply brought together, during the 1990s, in a further series of basic structure debates regarding 'judicial independence' vis-à-vis the definition of an implied constitutional right to 'secularism'.

23 The Constitution (Thirty-ninth Amendment) Act 1975 (39th Amendment).

24 Indira Nehru Gandhi v Raj Narain, 1975 ASC 1590, (1975) SCC (Supp) 1 (Supreme Court of India).

25 The Constitution (Forty-second amendment) Act 1976 (42nd Amendment). Lloyd and Susanne Rudolph note that unofficial papers illuminated a larger political context in which the government also considered introducing a special Judicial Council to subordinate the judiciary to executive control: Rudolph and Rudolph (n 16) 114, 440 fn 34.

26 Lloyd and Susanne Rudolph describe this Amendment as 'tantamount to a new constitution': Rudolph and Rudolph (n 16) 115.

27 Minerva Mills Ltd v Union of India (1980) 2 SCC 591.

28 On the independence of the judiciary, see also SP Gupta $v$ Union of India, AIR 1982 SC 149 (Supreme Court of India). 


\section{B. Basic Structure, the Separation of Powers, and Secularism}

Within the list of 'essential features' mentioned above, political circumstances in India revolving around the rise of Hindu-nationalist parties during the 1980s and 1990s - in particular, the rise of a party known as the Bharatiya Janata Party (BJP) - pushed the Supreme Court to revisit and revise many of its basic structure priorities. In particular, writing in 1987, Lloyd I Rudolph and Susanne H Rudolph noted that the Supreme Court decisions slowly learned to 'read [India's] election returns' in a 'politically responsive' way. $^{29}$

In the landmark case of SR Bommai $v$ Union of India, the Supreme Court extended its basic structure jurisprudence to a legal-cum-political context in which, strikingly, there was no constitutional amendment at stake. ${ }^{30}$ Returning to its description of 'secularism' as an essential feature of India's Constitution in Kesavananda, the Court took aim at the right-wing religious ideology of certain state-level governments. It noted that even in states led by elected governments where there was no breakdown in public order, constitutional provisions requiring the federal government to ensure that states 'carried on in accordance with [constitutional principles]' (Article 355) allowed the imposition of President's rule (Article 356) if a state could be shown to deviate significantly from the Constitution's essential features (in this case, 'secularism').

In Bommai, the Court focused on Himachal Pradesh, where - despite the election of a Hindu-nationalist government in 1990 - there was none of the public violence that plagued so much of India following a 1992 effort by Hindu nationalists to tear down a disputed mosque in Ayodhya. ${ }^{31}$ Moving beyond the question of public violence, the Court examined the palpably religious rhetoric of the manifesto issued by the statelevel ruling party (the BJP), holding unanimously that insofar as state-level leaders had vociferously supported key vigilantes in Ayodhya, they had materially violated the Constitution's essential features by ignoring its commitment to 'secularism'. ${ }^{32}$

In short, the Court reshuffled its configuration of constitutional features: even as the parliamentary form of government and federalism were demoted, secularism and the independence of the judiciary were promoted. ${ }^{33}$ Gary Jacobsohn called this ruling 'the most significant interpretation of the secular character of the Indian constitution to date', not only in terms of its reference to constitutional basic structure, but also in terms of the constitutional politics that followed from the Court's interpretation of 'secularism' as an essential feature of that structure. ${ }^{34}$ This political fallout focused, inter alia, on parliamentary efforts to control (via parliament's constituent power) the process of judicial appointments.

Specifically, Jacobsohn describes the BJP's establishment of a special commission known as the National Commission to Review the Working of the Constitution

29 The Court understood that 'the executive, acting ... with the support of parliamentary majorities', could act in ways that 'constrain[ed] citizens' rights', Rudolph and Rudolph (n 16) 118.

30 SR Bommai $v$ Union of India (1994) 3 SCC 1.

31 Protesters argued that the mosque in Ayodhya had been built on the birthplace of Lord Ram.

32 'The destruction of the mosque was ... concrete proof of the creed which the party in question wanted to pursue ... In such circumstances, the [state-level] ministries formed by the said party could not be trusted to follow the objective of secularism which was part of the [Constitution's] basic structure': SR Bommai (n 30) 143 (PB Sawant J); also quoted in Gary Jeffrey Jacobsohn, The Wheel of the Law: India's Secularism in Comparative Constitutional Context (Princeton University Press 2003) 145.

33 See Manoj Mate, 'Judicial Supremacy in Comparative Constitutional Law' (2017) 92 Tulane Law Review 393, 424-28; Jacobsohn, The Wheel of the Law (n 32) 114-34.

34 Jacobsohn, The Wheel of the Law (n 32) 175. 
(NCRWC) six years later as a commission explicitly designed to assess the need for further constitutional amendments 'without interfering with [the Constitution's] basic structure'. ${ }^{35}$ Downplaying any link between basic structure and religion-state relations or 'secularism', the NCRWC began its work by recommending procedural changes affecting judicial appointments. These recommendations culminated in India's ninetyninth constitutional amendment (99th Amendment). ${ }^{36}$

Passed in 2014 under BJP Prime Minister Narendra Modi with a lower-chamber vote of 367-to-0 (37 abstentions), an upper-chamber vote of 179-to-0 (1 abstention), and support from more than half of India's states - clearly discharging any procedural requirements for constitutional amendments - the 99th Amendment sought to change, via the creation of a National Judicial Appointments Commission (NJAC), the appointment procedures for superior judges. ${ }^{37}$ In short, the BJP built on its absolute majority following India's 2014 general election to elevate the role of parliament in appointing judges who might, in due course, return to questions regarding the 'secular' qualifications of elected legislators themselves.

Since 1993, India's federal and state-level Chief Justices had controlled the process of judicial appointment along with a small number of senior judges on each affected court. This judicial 'collegium' sent its recommendations to the President and, in the case of state-level High Court judges, to each state-level Governor for appointment. ${ }^{38}$ The 99th Amendment, however, sought to address emerging concerns about a lack of transparency in the collegium. Specifically, it introduced a six-member appointments commission - the NJAC - including the Supreme Court Chief Justice, two additional justices, the Law Minister, and two 'eminent persons' (potentially, persons with no legal background whatsoever chosen by a sub-committee of the Chief Justice, the Prime Minister, and the leader of the parliamentary opposition). The 99th Amendment further stipulated that judicial nominees could be vetoed by any two members of the NJAC, including those with no legal background at all.

In Supreme Court Advocates-on-Record Association v Union of India, however, the Supreme Court annulled this amendment. Since the government was the most frequent litigant in the superior courts, the Court was worried that frequent interaction with the Law Minister (on the NJAC) would undercut the independence of the judiciary. ${ }^{39}$ In effect, the Court noted that 'the primacy of the judiciary in the appointment process [is] an essential ingredient of the independence of the judiciary, which [is, itself, a] basic feature of the constitution and, therefore, beyond the realm of amendment'. ${ }^{40}$

35 ibid 133; AG Noorani described the NCRWC as 'an instrument for implementing the BJP's hidden agenda': Jacobsohn, The Wheel of the Law (n 32) 140 fn 95.

36 The Constitution (Ninety-ninth Amendment) Act 1971 (99th Amendment).

37 See Mate (n 33) 440-41.

38 The government was entitled to object to the collegium's recommendations, but if the relevant procedures were followed and the judges unanimously agreed, previous litigation clarified that the government was bound to accept whatever the judges had recommended. See Supreme Court Advocates-on-Record Association v Union of India, AIR 1994 SC 268 (Supreme Court of India).

39 Supreme Court Advocates-on-Record Association v Union of India (n 7) 574-75; see also Mate (n 33) 441-43 and Rehan Abeyratne, 'Upholding Judicial Supremacy in India: The NJAC Judgment in Comparative Perspective’ (2017) 49(3) George Washington International Law Review 569, 574.

40 V Venkatesan, 'Judicial Assertion' Frontline (Chennai, 13 November 2015) 7 <www.frontline.in/cover-story/judicial-assertion/article7809211.ece> accessed 4 October 2018; see also Mate (n 33) 410-11; Abeyratne (n 39). Abeyratne's 'institutional' reading of Supreme Court Advocates-on-Record Association (n 7) notes that, insofar as many democracies do not require judicial primacy vis-à-vis appointments as a marker of 'judicial independence', India is an outlier, with Supreme Court Advocates-on-Record Association (n 7) revealing little more than the judiciary’s 'reluctance to cede its supremacy to the executive and legislative branches': Abeyratne (n 39) 570. 
Again, this case did not directly consider the issue of religion-state relations or parliamentary disqualifications owing to any lack of adherence to 'secularism'; it focused on judicial appointments. However, alongside this focus on appointments, it is difficult to ignore the legacy of Bommai in relation to the BJP. Indeed, one might ask: how could the judiciary remain impartial in its judgment of a Hindu-nationalist government's commitment to 'secularism' if that judiciary was, itself, appointed by the government in question?

There is as yet no indication that, combining its oft-cited appreciation for judicial independence (Supreme Court Advocates-on-Record ${ }^{41}$ ) with a Bommai-style appreciation for secularism, the Supreme Court might reach beyond its earlier focus on state-level politics to remove a BJP Prime Minister (citing, once again, his or her lack of commitment to the Court's understanding of 'secularism'). ${ }^{42}$ But could it? Such hypothetical questions are illuminating. In particular, with reference to basic structure jurisprudence, they draw attention to the presence of a potentially powerful link between assertions of 'judicial independence' and institutionally competitive efforts to define parliamentarians' engagement with 'secularism'.

In India, basic structure jurisprudence is closely tied to considerations of religionstate relations. However, in practice, this link has partly taken shape via basic structure questions regarding judicial independence - above all, questions pertaining to appointments. Who will assemble the Court charged with demarcating parliament's authority to shape (or reshape) its constitutional relationship with religion?

\section{BASIC STRUCTURE IN PAKISTAN: PARLIAMENTARY POWER 'BLENDED WITH ISLAMIC PROVISIONS'}

From the start, debates regarding constitutional basic structure in Pakistan have been bound up with debates regarding the constitutional status of those claiming to interpret, not 'secularism', but 'Islam'. Even in 1953, Pakistan's Constituent Assembly sought to address the relative power of: (1) the parliament; (2) the courts; and (3) Pakistan's ulama (religious scholars), noting that, insofar as Pakistan sought to ensure that no legislation would be 'repugnant to the Quran and Sunnah', it would have to define the nature of the public authority charged with evaluating 'repugnancy'. ${ }^{43}$ Should that authority involve a board of religious scholars - what some described as a Mulla (sic) Board - or should it be confined to the courts? ${ }^{44}$ According to one Constituent Assembly member, ' $[t]$ he legislature might have the paramount voice in passing enactments', but if an enactment were accused of repugnancy, 'that case should go to the ... Court' ${ }^{45}$

For a similar argument, focusing on Pakistan, see Osama Siddique, 'Across the Border' (Seminar, November 2010) <www.india-seminar.com/2010/615/615_osama_siddique.htm> accessed 4 October 2018.

41 (n 7).

42 So far, election law decisions have been criticised for failing to rein in Hindu majoritarianism see Sathe (n 21) 182-91; Brenda Cossman and Ratna Kapur, Secularism's Last Sigh? Hindutva and the (Mis)Rule of Law (OUP 1999) 113.

43 See Clark B Lombardi, 'Designing Islamic Constitutions: Past Trends and Options for a Democratic Future’ (2013) 11 International Journal of Constitutional Law 616. Lombardi focuses on ordinary 'laws' rather than constitutional amendments.

44 Constituent Assembly of Pakistan Debates 9 October 1953, vol 15, 88 (Chaudhri Nazir Ahmad Khan).

45 Constituent Assembly of Pakistan Debates 22 October 1953, vol 15, 317 (Abdulla al-Mahmood). This view privileging the Courts over the ulama (who, in arts 228-30, were provided with an advisory 
By and large, Pakistan's constitutional drafters followed in the footsteps of an early20th-century Muslim philosopher named Mohammad Iqbal, stressing the preeminence of parliament whenever the state sought to recast the principles of Islam as some type of statutory or constitutional law. ${ }^{46}$ In doing so, they largely rejected the views of eminent personalities like Muhammad Asad, who sought to privilege the courts. ${ }^{47}$ In fact, just as India struggled to define the relative power of parliament with respect to the preservation of fundamental rights, Pakistan struggled to define the relative power of parliament vis-à-vis both fundamental rights and the specific notion that all laws should be ‘brought into conformity with ... Islam' (Article 227). ${ }^{48}$ Whereas India came to the conclusion that fundamental rights were an essential feature of its Constitution that could be reinterpreted, but never 'taken away' or 'abridged', Pakistan came to see the principles of the Quran and Sunnah as constitutionally salient features that could be framed (via the interpretive powers of parliament) in a statutory form, but not in any way that might be seen (by judges) as 'repugnant to the injunctions of Islam' ${ }^{49}$

\section{A. Basic Structure and Pakistan's 'Objectives Resolution'}

In assessing the constitutionality of Pakistan's first military dictatorship (1958-70), the case of Asma Jilani v Government of Punjab specifically addressed a series of questions regarding the extent to which the injunctions of 'Islam' stood above, and governed, the rest of the Constitution. ${ }^{50}$

Drawing attention to religious references within Pakistan's preambular Objectives Resolution (as some type of constitutional grundnorm or 'basic structure'), Supreme Court Chief Justice Hamood-ur-Rahman turned to Pakistan's delicate constitutional balance between Almighty Allah and the authority of the Pakistani people - rather than one individual or dictator. If any constitutional grundnorm were 'necessary', he argued, turning to Hans Kelsen's notion of 'supra-constitutional' authority, Pakistan need not 'look to ... Western legal theorists to discover one'. 'Our own grundnorm', he argued, is plainly enshrined in 'our own doctrine, ... which was clearly accepted in the Objectives Resolution'. ${ }^{51}$

Touching directly on the relationship between basic structure jurisprudence and religion, or religion-state relations, Chief Justice Hamood-ur-Rahman's reference to core principles that lay beyond the realm of explicitly justiciable text (for example, in Pakistan's constitutional preamble) was also reiterated in a later case concerning the competence of Pakistan's first post-martial law National Assembly (1972-77) to frame a new constitution and, in connection with this, the power of the court to strike down any new provision that might be considered 'repugnant' to the injunctions of Islam.

role), reflected a position formulated by Muhammad Asad (later embraced by Syed Abul ala Maududi); see Leonard Binder, Religion and Politics in Pakistan (CUP 1961) 238, 265-66.

46 See Matthew J Nelson, 'Islamic Law in an Islamic Republic: What Role for Parliament' in Asli Ü Bali and Hanna Lerner (eds), Constitution Writing, Religion and Democracy (CUP 2017) 235.

47 Binder (n 45) 238, 265-66.

48 See Nelson 'Islamic Law in an Islamic Republic' (n 46).

49 In her discussion of basic structure jurisprudence in Pakistan, Newberg notes that, whereas Indian cases like Kesavananda (n 3) 'discussed constitutional structures in terms of parliamentary sovereignty and judicial powers, in Pakistan these concerns [were] ... translated into ... the ideological-cum-religious basis of the state and [the] prospects for representative ... governance': Newberg (n 4) 240.

50 Asma Jilani v Government of Punjab, PLD 1972 SC 139 (Supreme Court of Pakistan).

51 Asma Jilani (n 50) 182. 
Originating in the Lahore High Court as Zia-ur-Rahman $v$ The State, this case illuminated a range of opinions regarding the link between constitutional 'basic structure' and the specific authority of Islam as it appeared in the Objectives Resolution. Justice Sajjad Ahmad, for instance, followed Chief Justice Hamood-ur-Rahman in describing the Objectives Resolution as a grundnorm, even as Justice Afzal Zullah took one step further, describing it as a 'supra-constitutional instrument' that was 'so fundamental and contain[ed] such mandates that it [could] not ... be repealed or abrogated' ${ }^{52}$

Writing for the majority, however, Justice AR Sheikh held that, even if Pakistan's Objectives Resolution could be regarded as a constitutional grundnorm, its references to Islam could not be applied in ways that reflected India's evolving notion of 'basic structure'. Specifically, Justice Sheikh explained that it could not be used to test the vires of the Constitution itself. ${ }^{53}$ In fact, when this case was finally elevated to the Supreme Court and decided on appeal in 1973, the basic thrust of the Court's judgment was entirely in keeping with Justice Sheikh's opinion. ${ }^{54}$ Rejecting any further tilt in the direction of India's basic structure jurisprudence (as expressed just a few years earlier in Golak Nath), the Court held that insofar as the Objectives Resolution served as a nonjusticiable preamble, it could not be read as any supra-constitutional 'instrument' controlling the rest of the Constitution. ${ }^{55}$ Specifically, clarifying his own earlier reference to constitutional grundnorms, Chief Justice Hamood-ur-Rahman noted that Pakistan's Supreme Court had 'never claimed ... the right to strike down any provision of the constitution'. ${ }^{56}$

Not surprisingly, several subsequent judgments went on to place this blanket rejection of binding supra-constitutional principles alongside a more sympathetic embrace of the Constitution’s religious ‘salient features'. In Islamic Republic of Pakistan v Abdul Wali Khan, for instance, Justice Gul Muhammad traced Pakistan's supreme constitutional authority directly to the text of the Quran. ${ }^{57}$ But, even then, the Court's majority followed Zia-ur-Rahman in rejecting the logic of Golak Nath and Kesavananda, stressing that the judiciary was not empowered to annul any provision of the Constitution and noting that 'this court [remains] committed to the view that "the judiciary cannot declare any [constitutional] provision ... to be [either] invalid or repugnant" , 58

In Federation of Pakistan v United Sugar Mills, the Court went on to reiterate that constitutional amendments could not be annulled on the basis of any 'abstract concept' claiming to represent an extra-constitutional notion of 'basic structure' ${ }^{59}$ Further, in Fauji Foundation $v$ Shaminur Rehman, the Court explained that 'no provision of the Constitution [could be deemed] ultra vires, because there is no touchstone outside the

52 Zia-ur-Rahman $v$ the State, PLD 1972 Lahore 382, 390 (Lahore High Court); also quoted in Muhammad Munir, 'Precedent in Islamic Law with Special Reference to the Federal Shariat Court and the Legal System in Pakistan’ (2008) 47(4) Islamic Studies 445, 454.

53 Munir (n 52) 454.

54 The State v Zia-ur-Rahman, PLD 1973 SC 49 (Supreme Court of Pakistan).

55 See Munir (n 52) 454 citing Zia-ur-Rahman (n 54) 71. Justice Khanna in Kesavananda (n 3) articulated a similar line of reasoning regarding the basic structure status of constitutional preambles four months later.

56 Quoted in District Bar Association, Rawalpindi (n 7) 45.

57 Islamic Republic of Pakistan v Abdul Wali Khan, PLD 1976 SC 57 (Supreme Court of Pakistan); see also Newberg (n 4) 244.

58 Zia-ur-Rahman (n 52) 76.

59 Federation of Pakistan v United Sugar Mills, PLD 1977 SC 397 (Supreme Court of Pakistan). 
Constitution by which the validity of [such] a provision ... [could] be judged' ${ }^{60}$

Still, ongoing efforts to identify the religious underpinnings of Pakistan's constitutional basic structure did not disappear. In the Lahore High Court case of Darwesh M Arbey v Federation of Pakistan, for instance, Justice Shameem Hussain Kadri provided a list of the Constitution's 'salient features' that included both the preambular Objectives Resolution and the notion of religious 'repugnancy' associated with the Constitution's advisory Council of Islamic Ideology (Article 227). ${ }^{61}$ In fact, in a related Arbey opinion, Justice Zakiuddin Patel connected the Objectives Resolution directly to the notion of enforceable unamendability underpinning Kesavananda: ' $[\mathrm{t}] \mathrm{he}$ basic structure ... and [the] essential features [of Pakistan's constitution]', he noted, 'have been fully given in the preamble, ... which is an integral part thereof, ... [so] any amendment to change them would be void'. ${ }^{62}$ Indeed, drawing attention to Pakistan's delicate balance between parliamentary authority and Islam, Justice Patel claimed that any effort to change the democratic character of Pakistan, to define Pakistan as a secular state, or to delete Article 2 (identifying Islam as the state religion) would amount to a prima facie violation of Pakistan's constitutional 'basic structure'. ${ }^{63}$

Clearly, the notion of constitutional basic structure was not unknown in Pakistan. In fact, when it emerged - even without the annulment of duly promulgated constitutional amendments - it was closely tied to complex constitutional debates regarding the formal legal position of 'Islam'.

\section{B. Debating Kesavananda within an 'Islamizing' State}

In 1985, under the 'Islamizing' dictator General Zia-ul-Haq, Pakistan's National Assembly introduced an omnibus constitutional amendment known as the Eighth Amendment (8th Amendment). ${ }^{64}$ This amendment, inter alia, rebranded Pakistan's (non-justiciable) preamble - also known as the Objectives Resolution - as an enforceable article within the Constitution itself (Article 2A). This change was designed to counter views articulated in Zia-ur-Rahman suggesting that a formal, textual, nonpreambular constitutional provision referring to 'the limits prescribed by [Allah]' could provide Islamizing activists with a powerful constitutional 'instrument' to strike down other (ostensibly 'un-Islamic') parts of the Constitution. The Supreme Court, however, disagreed.

Initially, Justice Tanzil-ur-Rahman of the Sindh High Court held that Article 2A functioned like Article 227 (regarding religious 'repugnancy') on steroids: ‘[a]ny provision of the constitution ... found repugnant to [Article 2A, he noted, could] ... be declared ... as void'. ${ }^{65}$ In Irshad $H$ Khan v Parveen Ijaz, Justice Rahman was even more direct, noting that Article 2A's reference to the sovereignty of Allah controlled the rest of the Constitution. ${ }^{66}$ Clearly, drawing attention to the language of the

60 Fauji Foundation v Shamimur Rehman, PLD 1983 SC 457 (Supreme Court of Pakistan), quoted in District Bar Association, Rawalpindi (n 7) 50, 199 and Roznai, Unconstitutional Constitutional Amendments (n 1) 49.

61 Darwesh M Arbey v Federation of Pakistan, PLD 1980 Lahore 206 (Lahore High Court).

62 Darwesh M Arbey (n 61) 297; also Munir (n 52) 455 fn 55. Evidently, Patel ignored the addition of 'we, the people of Pakistan' at the start of Objectives Resolution in 1973. This change was rejected in 1949 and, then, removed again in 1985.

63 Munir (n 52) 455 fn 55; Roznai, Unconstitutional Constitutional Amendments (n 1) 49.

64 The Constitution (Eighth Amendment) Act 1985 (8th Amendment).

65 Bank of Oman Ltd v East Trading Co Ltd, PLD 1987 Karachi 404, 445 (Sindh High Court).

66 Irshad H Khan v Parveen Ajaz, PLD 1987 Karachi 466 (Sindh High Court); see Munir (n 52) 456. 
Objectives Resolution, Justice Rahman sought to promote an immediate link between basic structure jurisprudence and his own understanding of Islam.

This push to close the gap between basic structure jurisprudence and explicit references to Islam in the Objectives Resolution, however, failed repeatedly. In fact, two Supreme Court decisions intervened to stop Justice Rahman in his tracks. Specifically, Hakim Khan $v$ Government of Pakistan and Kaneez Fatima $v$ Wali Muhammad reiterated the Supreme Court's view that references to Islam in Article 2A could not be used as supra-constitutional references overriding other articles of the Constitution. ${ }^{67}$ In Hakim Khan, Chief Justice Nasim Hasan Shah noted that each constitutional article must be read as equal so that, in each judgment, the Constitution could be read 'as a whole' ${ }^{68}$ And, in Kaneez Fatima, Justice Saleem Akhtar held that Article 2A could not be 'pressed into service for striking down any [other] provision of the constitution'. 69

As part of the same 8th Amendment that introduced Article 2A, however, Article 239 concerning constitutional amendments was also adjusted via two new sub-clauses. These two sub-clauses - Articles 239(5) and 239(6) - were borrowed, almost verbatim, from India's (already nullified) 42nd Amendment. Article 239(5), which mirrors India's Article 368(4), states that '[n]o amendment of the Constitution shall be called in question in any court on any ground whatsoever'. Article 239(6), which mirrors Article 368(5) of the Indian Constitution, provides that, '[f]or the removal of doubt, it is hereby declared that there is no limitation whatever on the power of the Majlis-eShoora (Parliament) to amend any of the provisions of the Constitution'. These clauses sought to shore up an already existing pattern in which - despite borrowing from India - the practical features of India's post-Kesavananda basic structure jurisprudence (viz striking down duly promulgated amendments) were simultaneously held at bay. Still and perhaps not surprisingly - they also spurred a greater appreciation for the role of judicial review within Pakistan's Supreme Court. ${ }^{70}$

In 1997, for instance, the Supreme Court decided to review the constitutionality of the 8th Amendment, even despite the introduction of Articles 239(5) and (6). Explicitly referencing the 'salient-features' language of Kesavananda in a landmark judgment known as Mahmood Khan Achakzai v Federation of Pakistan, the Court held that a careful reading of Article 2A alongside the Constitution 'as a whole' was sufficient to draw out a sense of the Constitution's salient features and its underlying basic structure. ${ }^{71}$ In particular, Chief Justice Sajjad Ali Shah stated that 'Article 2A, when read with other provisions of the constitution, reflects salient features ... highlighting [a] parliamentary form of government blended with Islamic provisions', with Muhammad Munir adding that, according to Chief Justice Shah, parliament's power 'to amend the constitution did not extend to amending [these] salient features' ${ }^{72}$

67 Hakim Khan v Government of Pakistan, PLD 1992 SC 595 (Supreme Court of Pakistan); Kaneez Fatima $v$ Wali Muhammad, PLD 1993 SC 901 (Supreme Court of Pakistan).

68 Quoted in District Bar Association, Rawalpindi (n 7) 227.

69 Quoted in District Bar Association, Rawalpindi (n 7) 72.

70 In 1996, a constitutional amendment pertaining to judicial appointments (and, thus, questions regarding the independence of the judiciary) led the Court one step closer to a Kesavananda-style understanding of basic structure. In Al-Jehad Trust v Federation of Pakistan, PLD 1996 SC 324 (Supreme Court of Pakistan), the Court partially modified its view in Hakim Khan (n 67) suggesting that art 2A should be read as 'the portion articulating the whole'. Still, the impugned amendment was allowed.

71 Mahmood Khan Achakzai v Federation of Pakistan, PLD 1997 SC 426 (Supreme Court of Pakistan); see also Roznai, 'Unconstitutional Constitutional Amendments' (n 2) 696.

72 Achakzai (n 71) 458 (emphasis added); Munir (n 52) 457. 
Still, Justice Saleem Akhtar and Justice Raja Afrasiab Khan insisted that Article 2A could not be read as an indicator of the Constitution's 'basic structure'. Writing for the Court's majority, Justice Akhtar flatly declared that 'the theory of basic structure' had always been 'completely rejected' in Pakistan. ${ }^{73}$

Even as the Court upheld the 8th Amendment in keeping with the views articulated by Justice Akhtar, however, the Court went on to declare that henceforth, and notwithstanding the terms of Articles 239(5) and (6), the power not to validate a constitutional amendment should be seen as part of its gift. ${ }^{74}$

\section{Rejecting Kesavananda in a Bid to Preserve 'Parliamentary' Power}

Just three years later, in the case of Zafar Ali Shah v General Musharraf, the Court returned to this more proactive view in a case examining the military coup led by General Pervez Musharraf in 1999. In this case, the Court held that even if Musharraf was (as per some coercive 'doctrine of necessity') practically empowered to amend the Constitution, he was, nevertheless, not constitutionally empowered to subvert its enduring basic structure. ${ }^{75}$ In referring to that structure, the Court drew attention to the work of a parliament 'blended with Islamic provisions' alongside the work of an independent judiciary. ${ }^{76}$

However, even as it tiptoed to within just a few inches of the interdictive logic articulated in Kesavananda, Pakistan's Supreme Court opted to hold its judicial fire. The Court did not invalidate any of the amendments introduced by General Musharraf. As Yaniv Roznai pointed out, writing in 2013, Pakistani references to constitutional basic structure had come to resemble empty rhetoric: Pakistan had a tendency to recognize basic structure limits, including religious limits, without in any way enforcing them. ${ }^{77}$

Nonetheless, in Pakistan Lawyers Forum v Federation of Pakistan (commonly known as the 17th Amendment Case), the Court began to clarify its rather complex position - what Waqqas Mir referred to as a 'descriptive' rather than a 'proscriptive' position. ${ }^{78}$ In particular, turning to the political logic surrounding the Court's cautious relationship with basic structure in a context framed by military dictatorship, the Court

73 Quoted in District Bar Association, Rawalpindi (n 7) 53.

74 Quoted in District Bar Association, Rawalpindi (n 7) 21. Clearly, the Court was divided. In a case regarding the fourteenth amendment to the Constitution (The Constitution (Fourteenth Amendment) Act 1997 (14th Amendment)) barring partisan floor-crossing (art 63A), Chief Justice Ajmal Mian led a majority in refusing to recognize any constitutional 'basic structure': Wukala Mahaz Barai Tahafaz Dastoor v Federation of Pakistan, PLD 1998 SC 1263, 1313 (Supreme Court of Pakistan). While Justice Saleem Akhtar thought that there might be such a structure, Justice Mamoon Kazi, writing for the minority, insisted that there was such a structure (ibid 1436). Justice Raja Afrasiab Khan adjusted his earlier position in Achakzai to hold that, ultimately, fundamental rights and the Islamic character of the state could not be repealed (ibid 1423). In its final judgment, the Court seemed to waffle: even if there were a constitutional basic structure against which constitutional amendments could be assessed, the 14th Amendment was allowed to stand because it was not found to violate whatever that structure might be; see District Bar Association, Rawalpindi (n 7) 215.

75 Waqqas Mir, 'Saying Not What the Constitution is ... But What It Should be: Comment on the Judgment on the 18th and 21st Amendments to the Constitution' (2015) 2 LUMS Law Journal 64, 69; for constraints on the amending power of a dictator, see also Fazlul Quader Chowdhry (n 18).

76 Syed Zafar Ali Shah v General Pervez Musharraf, PLD 2000 SC 869 (Supreme Court of Pakistan); see also Roznai, Unconstitutional Constitutional Amendments (n 1) 51.

77 Roznai, 'Unconstitutional Constitutional Amendments' (n 2) 697.

78 Mir (n 75) 69; Pakistan Lawyers Forum v Federation of Pakistan, PLD 2005 SC 719 (Supreme Court of Pakistan). 
examined General Musharraf's dual role as a civilian President and Chief of the Army Staff. This status was supported by the Seventeenth Amendment to Pakistan's Constitution (17th Amendment), ${ }^{79}$ which Musharraf's parliamentary allies introduced to exempt him from constitutional provisions barring 'dual offices' ${ }^{80}$

In this case, the Court held unanimously that, in Pakistan, constitutional amendments promulgated by parliament (in this case, a parliament led by a faction of the Pakistan Muslim League known as 'the king's party' for its loyalty to General Musharraf) could be challenged, but only 'on one ground': namely, that they had been 'enacted in a manner not stipulated by the constitution' (that is, via constitutional procedures referencing the power of parliament) ${ }^{81}$ In short, parliament's substantively unfettered constituent power was upheld, even when that power was seen as little more than a fig leaf for Musharraf's military dictatorship.

In Achakzai, the Court explained that 'the theory of basic structure or salient features ... has been used only as a doctrine to identify such features' ${ }^{82}$ It had not been used 'to strike down [duly promulgated] provision[s] on [any] substantive grounds' including, at least ostensibly, substantive religious grounds. ${ }^{83}$ In short, Pakistan's Supreme Court maintained that its ability to identify the salient features of the Constitution (including its 'Islamic' features) did not compel it to reject duly promulgated amendments that appeared to violate those features. There was, departing from Kesavananda and Bommai, no enforceable link between basic structure jurisprudence and substantive references to ‘Islam’.

\section{Embracing Kesavananda to Enhance the Independence of the Judiciary}

Finally, in 2015, and for the first time ever, 13 out of 17 judges sitting on a full bench of Pakistan's Supreme Court firmly rejected the view espoused in the 17th Amendment Case, holding that prior forms of judicial deference to parliament's constituent power could - by drawing on some of the basic structure thinking in Achakzai and Zafar Ali Shah - potentially be altered at some unspecified point in the future. ${ }^{84}$ This development in the case of District Bar Association, Rawalpindi $v$ Federation of Pakistan did not directly reference the substantive terms of Islam. Following India (Supreme Court Advocates-on-Record), it simply opened up the possibility of a closer link between basic structure jurisprudence and religion via basic structure thinking regarding 'judicial independence' in the realm of judicial appointments.

District Bar Association, Rawalpindi v Federation of Pakistan concerned three constitutional amendments - namely, the eighteenth (18th Amendment), nineteenth

79 The Constitution (Seventeenth Amendment) Act 2003 (17th Amendment).

80 Art 63(1)(d) barred parliamentarians from holding a military or a bureaucratic 'office for profit' ... 'other than an office declared by law'; Musharraf simply passed a law allowing the President to serve as Chief of the Army Staff.

81 Roznai, Unconstitutional Constitutional Amendments (n 1) 51; Roznai (n 2) 698 (citing 17th Amendment Case (n 78) 27).

82 District Bar Association, Rawalpindi (n 7) 468.

83 See District Bar Association, Rawalpindi (n 7) 465 quoting 17th Amendment Case (n 78) paras 41, 56-57: 'The superior courts of this country have consistently acknowledged that while there may be a basic structure to the constitution, and while there may also be limitations on the power of parliament to make amendments to such basic structure, such limitations are to be exercised and enforced not by the judiciary ... but by the body politic, i.e. the people of Pakistan'.

84 Mir (n 75) 66 called this 'the most important ruling on a constitutional question in the history of Pakistan'; see also Siddique, ‘Across the Border' (n 40). 
(19th Amendment), and twenty-first (21st Amendment) constitutional amendments ${ }^{85}$ each touching, inter alia, on the principle of judicial independence. ${ }^{86}$ Responding to growing concerns about religious militancy in Pakistan, the 21st Amendment introduced a parallel system of military courts (renewable every two years) for the trial of civilians accused of religious terrorism (Article 175(3)). The 18th Amendment, like India's 99th Amendment, introduced a new Article 175A altering the procedure for appointing superior court judges. While the 21st Amendment appeared to engage, more directly, with religion (here, religious terrorism), it was actually the 18th Amendment regarding judicial appointments that reinvigorated enduring debates regarding the link between basic structure jurisprudence and religion-state relations in Pakistan.

Previously, as in India, the chief justices in Pakistan's Supreme Court and High Courts submitted judicial nominees to the President (or, in the case of provincial High Courts, the relevant provincial Governor) for selection. ${ }^{87}$ However, as in India's 99th Amendment, Pakistan's 18th Amendment sought to adjust this practice by introducing a new Judicial Commission (JC) with a mix of judicial and non-judicial members to prepare a list of candidates for consideration by a Parliamentary Committee (PC) that was empowered to reject the JC's recommendations (citing reasons that were, nevertheless, justiciable). ${ }^{88}$ This 18th Amendment was challenged in Nadeem Ahmed v Federation of Pakistan and, on the basis of a preliminary Supreme Court order, the 18th Amendment was referred back to parliament for revision. ${ }^{89}$ In particular, recalling some of the concerns surrounding India's 99th Amendment, Pakistan's Supreme Court recommended expanding the JC by two further Supreme Court justices (reinforcing a judicial majority and, within this, a majority held by Supreme Court justices) while, at the same time, reiterating that the JC was permitted to overrule any PC 'reasons' cited when rejecting nominees. These recommendations were accepted by Pakistan's National Assembly in the form of Pakistan's 19th Amendment. ${ }^{90}$

Building on Nadeem Ahmed, however, a 13-justice majority in the case of District Bar Association, Rawalpindi returned to the 18th, 19th, and 21st Amendments. The majority held - for the first time - that although Articles 239(5) and 239(6) might oust the jurisdiction of the 'courts' from any power to review duly promulgated constitutional amendments, these articles were not intended to oust the overarching jurisdiction of Pakistan's 'Supreme Court' in defending the Constitution (indeed, to do

85 The Constitution (Eighteenth Amendment) Act 2010 (18th Amendment); Constitution (Nineteenth Amendment) Act 2010 (19th Amendment); and the Constitution (Twenty-first Amendment) Act 2015 (21st Amendment).

86 District Bar Association, Rawalpindi (n 7).

87 The Court's decision in Al-Jehad Trust (n 69) rendered the role of the President (or Governor) largely redundant.

88 The PC was to have eight members - four from the National Assembly and four from the Senate (with an equal number from the government and the opposition) - empowered to reject JC nominees with six votes; see Osama Siddique, 'The Judicialization of Politics in Pakistan: The Supreme Court after the Lawyers' Movement' in Mark Tushnet and Madhav Khosla (eds), Unstable Constitutionalism: Law and Politics in South Asia (CUP 2015) 159.

89 Nadeem Ahmed v Federation of Pakistan, PLD 2010 SC 1165 (Supreme Court of Pakistan). 'To hold th[is] petition maintainable was a very strong statement in itself', notes Saroop Ijaz, since, historically, the Court had not '[sat] in judgment over constitutional amendments'; see Saroop Ijaz, 'Judicial Appointments in Pakistan: Coming Full Circle’ (2014) 1(1) LUMS Law Journal 86, 88.

90 These recommendations were challenged (unsuccessfully) in the case of Munir Hussain Bhatti $v$ Federation of Pakistan, PLD 2011 SC 407 (Supreme Court of Pakistan); see also Asmat Ullah Khan, 'Threats and Challenges to Parliamentary Supremacy in Pakistan from 2008-2013' (PhD thesis, Quaid-i-Azam University, 2018) 194-99. 
so would alter the Constitution's basic structure by distorting its balance of powers). ${ }^{91}$ Moreover, a clear majority held that henceforth, the Court was empowered to move beyond a purely 'descriptive' account of the Constitution's salient features (including 'a parliamentary form of government blended with Islamic provisions') in favour of 'proscriptive' judgments annulling duly promulgated amendments that might repeal, abrogate, or fundamentally alter those features. ${ }^{92}$

Within this 13-justice majority, however, eight justices decided that, although the possibility of annulment existed in theory, the 18th, 19th, and 21st Amendments should be upheld in practice. Only five justices held that, as in India (Supreme Court Advocates-on-Record), key portions of these amendments should be struck down as a violation of judicial independence. In effect, a slim majority returned to the minority views in Achakzai and Zafar Ali Shah, holding that although the impugned amendments would be allowed to stand, the power not to validate even duly promulgated amendments was still a part of its gift. ${ }^{93}$

Reviewing this decision, Waqqas Mir asked why the majority chose to assert its power of judicial review vis-à-vis constitutional amendments while, at the same time, reserving that power in practice. Focusing on the 21st Amendment, Mir notes that it was actually senior military commanders, not parliament, who wanted to see those accused of religious terrorism tried in military courts. In fact, he notes that basic structure jurisprudence focusing on 'the independence of the judiciary' may have been deployed as a check on military power. Addressing what many saw as a bid to constrain parliament's constituent power, Mir suggests that perhaps District Bar Association, Rawalpindi should be read, not as a case of judicial self-aggrandizement in matters pertaining to religion, but rather as a bid to constrain military compulsions masquerading as 'parliamentary' amendments. ${ }^{94}$

Like the Indian Supreme Court decision in Supreme Court Advocates-on-Record, the nearly simultaneous Pakistan Supreme Court decision in District Bar Association, Rawalpindi did not dwell on the issue of religion-state relations. Instead, it focused on civil-military relations and, turning to the 18th and 19th Amendments, the question of judicial appointments. Within just two years, however, the possibility of a more direct link between basic structure jurisprudence, judicial appointments, and religion-state relations had taken centre stage. This followed the emergence of new tensions between parliament and the judiciary after Pakistan's Supreme Court decided to remove Prime Minister Mohammad Nawaz Sharif from office. ${ }^{95}$

\section{E. Pakistan: Basic Structure, the Independence of the Judiciary, and Islam}

The specific logic underpinning Prime Minister Sharif's parliamentary disqualification introduced the possibility of an entirely new chapter in the relationship between basic structure jurisprudence, judicial independence, and the 'Islamic' characteristics of Pakistan's postcolonial parliament. This link grew out of the legal basis for Prime Minister Sharif's disqualification - a legal basis that originated in a corruption scandal

91 District Bar Association, Rawalpindi (n 7) 853-56.

92 Waqqas Mir (n 75); Achakzai (n 71). See also Roznai, Unconstitutional Constitutional Amendments (n 1); Lau (n 4) 91.

93 District Bar Association, Rawalpindi (n 7) 21.

94 Mir (n 74) 75.

95 Imran Ahmed Khan v Mian Muhammad Nawaz Sharif, 2017 PLD 692 SC (Supreme Court of Pakistan). 
involving offshore legal and financial records known as 'The Panama Papers'. In that scandal, Prime Minister Sharif was accused of failing to disclose promised income from a business owned by his son in Dubai. In fact the Supreme Court judgment removing Prime Minister Sharif from parliament was rooted in a constitutional provision (Article 62(1)(f)) requiring every Pakistani parliamentarian to be 'righteous', 'honest', and 'ameen' (ie, honest in a specifically religious sense). As Sharif had failed to disclose all of his 'receivable' income, he was considered 'dishonest' and formally disqualified on this basis. ${ }^{96}$

Immediately, Sharif's disqualification raised a number of questions regarding the prevailing trajectory of basic structure jurisprudence. A further hypothetical scenario may help to clarify the issues. If, at some point, any governing party seeking to avoid the fate of Prime Minister Sharif were to enjoy sufficient support in both houses of parliament, it could attempt to introduce a constitutional amendment seeking to remove or revise Article 62(1)(f), claiming that its notion of religious 'honesty' was prone to excessive judicial discretion. Indeed, such an amendment has already been proposed, not only in the press, but also in the scholarship of a lawyer later elevated to Pakistan's Supreme Court. ${ }^{97}$ However, if such an amendment were actually promulgated, there are fears that activists claiming to defend Pakistan's constitutional attachment to 'Islam' might resort to widespread street protests, pressuring Pakistan's Supreme Court to consider a 'basic structure' annulment striking down this amendment as a violation of the Constitution's essential features (namely, a 'parliamentary form of government blended with Islamic provisions').

In short, the Supreme Court could be called upon to combine its majority decision in District Bar Association, Rawalpindi (which asserts the possibility of Supreme Court oversight over constitutional amendments) with a 'Pakistani' reading of Bommai (replacing Indian 'secularism' with a special focus on 'Islam'). This could finally push Pakistan's engagement with the proscriptive logic of both Kesavananda and Bommai beyond the realm of legal theory and into the realm of practice. ${ }^{98}$ Indeed, cutting against so much of Pakistan's postcolonial Supreme Court jurisprudence, such a decision could finally position the Court as the first among equals in matters pertaining to Islam, pulling it away from the views articulated by Mohammad Iqbal (stressing parliamentary

96 See Saad Rasool, 'Distilling Eligibility and Virtue: Articles 62 and 63 of the Pakistani Constitution', (2014) 1(1) LUMS Law Review 39, 50-51. Rasool notes that provisions like art 62(f) were inserted by General Zia solely for the purpose of 'political victimization and witch-hunting': ibid 55. In 2012, the Supreme Court upheld the disqualification of Interior Minister Rehman Malik as 'dishonest' (art 62(f)) on the basis of a false declaration regarding his dual citizenship (art 63(c)): ibid 61. In 2013, the Court also removed Pakistan People’s Party Prime Minister Yusuf Raza Gilani; he was convicted of contempt of court (art 63(g)) for ignoring a court order requiring him to reopen a corruption case in Switzerland initiated by Nawaz Sharif against Benazir Bhutto and her widower Asif Zardari.

97 See Iftikhar A Khan, 'Government Reveals Plans to Amend Articles 62, 63' Dawn (Karachi, 23 August 2017) <www.dawn.com/news/1353269> accessed 4 October 2018; Hidayat Khan, 'Ironic: Nawaz Didn’t Let Articles 62, 63 Amended: Asfandyar’ The Express Tribune (Karachi, 29 July 2017) <https://tribune.com.pk/story/1469555/anps-asfandyar-calls-immediately-amending-article-62-6/> accessed 4 October 2018; Rameez Khan, 'If PML-N Wins, Law Will Be Amended to Make Sharif PM Again: Sanaullah’ The Express Tribune (Karachi, 14 March 2018) $<$ https://tribune.com.pk/story/1659313/1-pml-n-wins-law-will-amended-make-sharif-pmsanaullah/> accessed 4 October 2018; InpaperMagazine, 'Qualifications for Candidates - A Constitutional Puzzle’ Dawn (Karachi, 1 September 2017) <www.dawn.com/news/1355356> accessed 4 October 2018.

98 For an argument regarding the ‘Islamization’ of Pakistan's superior judiciary alongside assertions of judicial over political authority, see Moeen H Cheema, 'Beyond Beliefs: Deconstructing the Dominant Narratives of the Islamization of Pakistan's Law' (2012) 60(4) American Journal of Comparative Law 875, 894, 901-03, 909-10. 
pre-eminence in such matters) in favour of Muhammad Asad (positioning the Court as the final arbiter of what parliament's engagement with 'Islam' might actually be taken to mean). ${ }^{99}$

So far, no amendment seeking to remove Article 62(1)(f) has emerged in Pakistan, and the Supreme Court has not struck down any constitutional amendment duly promulgated by parliament. However, as argued above, in District Bar Association, Rawalpindi a full bench held that at some point in the future, it could. It is perhaps only a matter of time before this prospect is tested in a basic structure case addressing - and, probably, restricting - parliament's power to amend constitutional provisions that define its relationship with Islam. Like India's Supreme Court, which held up 'secularism' as an essential feature of the Indian Constitution while, at the same time, granting itself the power to define what a constitutional reference to secularism might mean, Pakistan's Court could easily hold up 'Islam' as an essential feature of its parliamentary form of government while, at the same time, giving itself (not the parliament or the ulama) the pre-eminent power to define it. ${ }^{100}$ In District Bar Association, Rawalpindi, Pakistan's Supreme Court simply ensured that, if this case emerges in the future, the Court will take the lead in appointing the judges empowered to decide what form parliament's relationship with religion should take.

\section{CONCLUSION}

Of late, constitutional debates regarding basic structure jurisprudence in both India and Pakistan have unfolded in a substantive domain largely divorced from explicit references to religion. They have unfolded, instead, in constitutional battles regarding the independence of the judiciary and, specifically, the process of judicial appointments. However, the relevance of these battles for those with an interest in religion-state relations is rarely missed; in effect, these battles concerning appointments underpin institutionally competitive efforts to assemble the courts that will, in time, determine the configuration of each country's relationship with religion.

In Pakistan, debates regarding basic structure jurisprudence have shifted over time, pulling away from efforts to constrain the power of parliament via explicit references to 'Islam' (for example, in the Objectives Resolution) toward more nuanced efforts to set aside a defining role for parliament vis-à-vis judicial appointments - indeed, restricting parliament's role in moulding the judiciary that will, in due course, draw on notions of constitutional 'basic structure' to shape the meaning of Pakistan's 'parliamentary form of government blended with Islamic provisions'. 101

Both Pakistan and India share a common aversion to British notions of parliamentary sovereignty (initially expressed in the constitutional enumeration of

99 Newberg (n 4) 243 notes that '[w]hile the [Supreme C] ourt acts as guarantor for elected government, to violate its judgment in the sensitive area of Islamic obligation [would be] to reignite a stateideology dispute in a form that secular government is [very] unlikely to win'; indeed, it is worth recalling that, even in India, sizable parliamentary majorities did not deter a Supreme Court turn to basic structure jurisprudence: Indira Gandhi (n 24) (1975; Congress Party majority 66\%); Supreme Court Advocates-on-Record (n 7) (2015; BJP majority 52\%); see also Siddique, 'The Judicialization of Politics in Pakistan' (n 86).

100 It is telling that, during the District Bar Association, Rawalpindi (n 7) proceedings, several judges seemed to revive the views of Justice Tanzil-ur-Rahman, balancing their appreciation for an enforceable understanding of constitutional 'basic structure' with a nod to art 2A; Siddique, 'Across the Border' (n 40) 3.

101 See eg Roznai, Unconstitutional Constitutional Amendments (n 1); Achakzai (n 71). 
fundamental rights and the establishment of an independent judiciary). Within this common point of departure, however, existing forms of engagement with constitutional 'basic structure' have also allowed for the advancement of two very different facets of Britain's approach to religion-state relations at once: whereas, in India, the judiciary has treated 'secular' governance as one of its constitutional essential features, Pakistan has sought to highlight the value of 'religious establishment'. Indeed, even as basic structure jurisprudence has begun to migrate, within South Asia, the secular basic structure jurisprudence of India's Supreme Court has facilitated the religious side of Pakistan's constitutional politics in a number of unexpected ways - ways that pull away from Mohammad Iqbal's push for parliamentary pre-eminence in delineating a formal legal approach to Islam in favour of Muhammad Asad's countervailing push to stress judicial pre-eminence. ${ }^{102}$

Given Yaniv Roznai's description of a truly global push favouring basic structure thinking in constitutional courts, efforts to promote a more 'judicialized' approach to religion-state relations could emerge even in countries like Sri Lanka where, like Pakistan, the courts began with a remarkable hesitation regarding the implications of Kesavananda before slowly changing their minds. ${ }^{103}$ What is interesting about such a prospect is the degree to which each country - India, Pakistan, and Sri Lanka - has relied on a remarkably similar basket of essential features (judicial independence, a parliamentary form of government, fundamental rights, debates regarding federalism, and religion-state relations) while, at the same time, adjusting the configuration of these elements in ways that reinforce judicial pre-eminence vis-à-vis each country's approach to religion: 'secularism' in India; 'Islam' in Pakistan; 'Buddhism' in Sri Lanka; and so on. ${ }^{104}$ As Rehan Abeyratne points out, a thorough understanding of basic structure jurisprudence (what Roznai calls a 'migrating' constitutional idea) requires empirically nuanced forms of judicial analysis. ${ }^{105}$ It is not merely the concept of basic structure, or a particular list of salient features, that migrates; it is also the contested configuration of those features with specific reference to religion.

Judiciaries may use basic structure jurisprudence as a vehicle for institutional selfaggrandizement versus parliament (in India) or versus both parliament and the military (in Pakistan). However, in both India and Pakistan, the ways in which existing forms of judicial self-aggrandizement are poised to control parliament's approach to religion cannot be overlooked. In both countries, the link between basic structure jurisprudence and religion-state relations has often been constructed indirectly. Indeed, the link between basic structure and religion is just one part of a much wider competition between parliamentary and judicial power: Hindu legislators versus an Indian Supreme Court claiming to defend its own notion of constitutional 'secularism'; Muslim legislators versus a Pakistani Supreme Court claiming to defend its own understanding

102 This line between Iqbal and Asad cuts to the core of Roznai's effort to defend activist courts underpinned by basic structure jurisprudence if their jurisprudence can be said to support 'the will of the people'; see Roznai, Unconstitutional Constitutional Amendments (n 1) 229-30. Where is this 'will’ located, vis-à-vis Islam, in Pakistan's constitutional basic structure: in parliamentary (Iqbal) or judicial (Asad) interpretations of Islamic injunctions?

103 See the decision of the Supreme Court of Sri Lanka on the 19th Amendment to the Constitution of Sri Lanka. Re A Bill Entitled 'The Nineteenth Amendment to the Constitution', SC Special Determination Nos 4-19/2015 (9 April 2015). Basic structure jurisprudence was considered especially unlikely in Sri Lanka, where the Constitution (art 82(5)) explicitly allows for 'the repeal and replacement of the constitution [itself]'.

104 On Sri Lanka's judicialized approach to religion-state relations, see Benjamin Schonthal, Buddhism, Politics and the Limits of Law: The Pyrrhic Constitutionalism of Sri Lanka (CUP 2016).

105 Abeyratne (n 39); Roznai, 'Unconstitutional Constitutional Amendments' (n 2). 
of ‘Islam’. 